\title{
Anti-Fertility Effects and Mechanism of the Plant Extract Shikonin on Mice
}

\author{
Heping Fu1,2*, Darhan Bao1,2*, Man Duhu ${ }^{1,2^{*}}$, Shuai Yuan', ${ }^{1 *}$, An Xing1,2, Suwen Yang1,2, \\ Xiaodong $\mathrm{Wu}^{1,2 \#}$ \\ ${ }^{1}$ Inner Mongolia Agricultural University, Hohhot, China \\ ${ }^{2}$ Key Laboratory of Prataculture and Grassland Resources, Ministry of Education, Hohhot, China \\ Email: fuheping@126.com, "wuxiaodong_hgb@163.com
}

Received 23 June 2016; accepted 14 August 2016; published 17 August 2016

Copyright (C) 2016 by authors and Scientific Research Publishing Inc.

This work is licensed under the Creative Commons Attribution International License (CC BY).

http://creativecommons.org/licenses/by/4.0/

(c) (i) Open Access

\begin{abstract}
Controlling fertility of rodent pests has become an effective means of controlling the population of grassland rodents in China. Recently, research has focused on how to select environmentallyfriendly sterilants without pollution effects, and to realize sustainable control of pest rodent populations. Sterilants from plant extracts have been mainly selected. In this study, mice were used as the experimental subjects for research on the anti-fertility effects of plant extracts of shikonin and the anti-fertility mechanism of shikonin extract was determined. The mice were divided into four groups, including one control group and three experimental groups. There were three applications of shikonin extract in different concentrations $\left(5 \mathrm{mg} \cdot \mathrm{kg}^{-1}, 20 \mathrm{mg} \cdot \mathrm{kg}^{-1}\right.$ and $\left.50 \mathrm{mg} \cdot \mathrm{kg}^{-1}\right)$. The mice gavage experiments indicated that a shikonin concentration of $50 \mathrm{mg} \cdot \mathrm{kg}^{-1}$ had the expected anti-fertility effects. Mice copulation experiments showed that the $50 \mathrm{mg} \cdot \mathrm{kg}^{-1}$ shikonin treatment had significant anti-fertility effects on both female-treatment and female-male-treatment groups. The results of the PCR analysis on the AgRP and ghrelin mRNA from female ovaries and male testicles indicated that shikonin could control mice reproduction by regulating the pituitary gonadal axis. Shikonin, as plant source sterile agent, would have more ideal effects for functioned both sexes sterility.
\end{abstract}

\section{Keywords}

Anti-Fertility, Mechanism, Plant Extract, Shikonin, Mice

\section{Introduction}

There has been a lot of research on fertility control in pest rodents, and some achievements have focused on the

*These authors contributed equally to this work.

"Corresponding author.

How to cite this paper: Fu, H.P., Bao, D., Duhu, M., Yuan, S., Xing, A., Yang, S.W. and Wu, X.D. (2016) Anti-Fertility Effects and Mechanism of the Plant Extract Shikonin on Mice. Journal of Biosciences and Medicines, 4, 30-39.

http://dx.doi.org/10.4236/jbm.2016.48005 
screening of sterilants, laboratory tests and the application of preliminary control on some wild populations [1]-[6]. In addition, theoretical exploration has been conducted of the population dynamics of pest rodents under fertility control, mainly based on ecological models [7]-[12]. Recently, research has focused on how to select environmentally-friendly sterilants without pollution effects, and to realize sustainable control of pest rodent populations. Sterilants from plant extracts have been mainly selected. Tran and Hinds (2013) summarized 13 plant extracts with anti-fertility effects on follicle formation in female rodents from more than 40 plants, and further proposed application routes and identified several extracts with potential [13]. In China, sterilants from plant sources that have been applied in the fertility control of pest rodents include Tripterygium wilfordii, gossypol, Ruta graveolens, Camellia oleifera, radix trichosanthis (Trichosanthes kirilowi), colchicine, semen ricini (Ricinus communis), aaruginous turmeric rhizome (Curcumae aeruginosae) and neem (Melia azederach). Though all of them had been made into baits for animal experiment in the laboratory or sprayed in the wild for animal foraging, which had a certain effects, the practical applications have been unsatisfactory [14]. And that the researches on different physiology, pathology, pharmacology and contraceptive effects of the shikonin are less [15]-[17].

Shikonin is an extract of the plant Arnebia euchroma that belongs to the perennial Boraginaceae and that is widely distributed in Inner Mongolia, Xinjiang and Gansu provinces [18]. It is recorded in "Shennong’s Herbal" that radices lithospermi has anti-inflammatory, anti-allergy, antipyretic, anti-tumor and anti-fertility effects. Previous research has mainly focused on the anti-inflammatory, anti-tumor and anti-HIV effects [15] [19], while there is rare, mostly experimental, evidence of its anti-fertility effects and the mechanism through which this effect occurs. In this study, three different concentrations of shikonin were applied for fertility control in mice, and its possible mechanism of action was analyzed. It is hoped that plant source sterilants, which are environmentfriendly and without pollution, can be applied for sustainable control of pest rodents.

\section{Materials and Methods}

\subsection{Materials}

Shikonin, an A. euchroma extract (molecular formula $\mathrm{C}_{16} \mathrm{H}_{16} \mathrm{O}_{5}$, analytical standard $\geq 97 \%$, molecular weight 288.30), was provided by Aladdin Reagent (Shanghai) Co. Ltd., China. The experimental animals were adult Kunming mice with body weights of 33.1 - 44.6 g provided by the Laboratory Animal Center of Inner Mongolia Agricultural University, and they were fed in clean laboratory, $12 \mathrm{~h}$ light-dark recycle, temperature $18^{\circ} \mathrm{C}$ to $22^{\circ} \mathrm{C}$, and air relative humidity $40 \%$ - 60\%. Suitable amounts of food and water were provided and the mice developed normally.

\subsection{Sectionalization of Mice}

The experimental mice were divided into four groups with 15 pairs in each group, with one group used as the control and the other three groups were given by gavage shikonin at $5 \mathrm{mg} \cdot \mathrm{kg}^{-1}, 20 \mathrm{mg} \cdot \mathrm{kg}^{-1}$ and $50 \mathrm{mg} \cdot \mathrm{kg}^{-1} \mathrm{con}-$ centrations. The shikonin was dissolved with edible oil, and each mouse was given $0.2 \mathrm{ml}$ oil-dissolved shikonin once, and twice a week with an interval of three days. The mice in the control group were given the same volume of edible oil using gavage. Dissections were conducted one week after the last gavage to determine four indices: female uterine organ coefficient, male seminal vesicle organ coefficient, sperm density and testicle organ coefficient. The organ coefficient was calculated using the following formula:

$$
\text { Organic coefficient }=\frac{\text { Organ weight }}{\text { Animal carcass weight }}
$$

The ideal shikonin concentration was selected for the reproduction tests. There was one control group with 15 pairs of mice and three experimental groups with 15 pairs in each group. There were three different treatments: male-treatment group (males with medicated treatment, females without medicated treatment), female-treatment group (females with medicated treatment, males without medicated treatment), and female-male-treatment group (both sexes with medicated treatment). The experimental groups were given shikonin at the ideal concentration, via gavage, twice a week with an interval of three days. The control group was given by gavage the same volume of edible oil. The males and females copulated one week after the last gavage, and the reproductive status of the mice was recorded. 


\subsection{Determination of Mice Sperm Density}

Ahemocytometer was used for counting under an optical microscope. In the $1 \mathrm{~mm}^{2}$ counting chamber, the number of sperm from the five squares in the center and the four corners of the 25 squares were calculated as follows:

Sperm density (total number of spermsml ${ }^{-1}$ ) $=$ sperm number $\times$ dilution ratio $\times 5 \mathrm{~mm}^{2} \times 10 \mathrm{um} \times 1000 \mathrm{ml}$.

\subsection{PCR Determination of Ghrelin and AgRP}

For the real-time qPCR analysis there were control and experimental mice groups, with five male and five female mice in each group. The ovaries and testicles were obtained as the experimental materials. To avoid contamination and interference with the genome, the primers were designed based on the cross-intron principle (shown in Table 1, synthesized by Shanghai Sangon Biotech Co., Ltd). The SYBR Green I method was applied to determine the real-time quantitative PCR amplification. The PCR reaction system with $20 \mu \mathrm{L}$ included $10 \mu \mathrm{L}$ $2 \times$ SYBR premix EX TaqTM (TaKaRa DRR041A), $0.4 \mu \mathrm{L}$ upstream/downstream primer each $\left(10 \mathrm{molL}^{-1}\right), 2$ $\mu \mathrm{L}$ cDNA and $7.2 \mu \mathrm{L}$ dH2O. The PCR reactions were conducted in a real-time quantitative PCR instrument (Bio-Rad CFX96) with the amplification conditions of pre-denaturation at $95^{\circ} \mathrm{C}$ for $30 \mathrm{~s}$, followed by 40 cycles of denaturation at $95^{\circ} \mathrm{C}$ for $15 \mathrm{~s}$, annealing at $58^{\circ} \mathrm{C}-60^{\circ} \mathrm{C}$ for $15 \mathrm{~s}$ and extension at $72^{\circ} \mathrm{C}$ for $15 \mathrm{~s}$, ending with extension at $72^{\circ} \mathrm{C}$ for $10 \mathrm{~min}$. Water was used to replace the cDNA as the negative control, and the relative expression quantity of the mRNA was calculated using the $2^{-\Delta \mathrm{ct}}$ method $(\Delta \mathrm{CT}=\mathrm{CT}$ target gene $-\mathrm{CT}$ reference gene).

RNA samples for qPCR extracted from ovaries and testis: RNA was extracted from ovaries and testis with the RN easy Kit (Qiagen, Germany). The RNA pellets were dissolved in nuclease-free water and concentrations were measured by spectrophotometry at $260 \mathrm{~nm} .6 .5 \mu \mathrm{RNA}$ aliquots were amplified.

All RNA per sample was also incubated with RNase-free DNase I to remove any remaining genomic contamination. For amplification of the targets, RT and PCR were run in two separate steps, RNA was reverse transcribed with Peimer Script TMRT ase (TaKaRa, Inc. Dalian, China) following the manufacturer's directions and performed at $37^{\circ} \mathrm{C}$ for $15 \mathrm{~min}$ for reverse transcription and then $84^{\circ} \mathrm{C}$ for 5 sec. to inactivate the reverse transcriptase.

The experiments were carried out in accordance with the guidelines issued by the Ethical Committee of Inner Mongolia Agricultural University.

\subsection{Data Analysis}

A one-way ANOVA and Tukey's Multiple Comparison test for the significance of the PCR results were conducted using the statistical software Graph-Pad Prism 5. The one-way ANOVA in SAS 9.0 was applied for the comparative analysis of the corresponding indices in the mice groups with different treatments as well as the number of offspring produced by the female mice. Statistical significance was assessed at $P<0.05$ level unless otherwise noted.

Table 1. Primer design table.

\begin{tabular}{|c|c|c|c|}
\hline Gene (accession no.) & Nucleotide sequence (5' - 3 ') & Product size (bp) & Annealing temperature $\left({ }^{\circ} \mathrm{C}\right)$ \\
\hline AgRP & & 215 & 58 \\
\hline Forward & AGA CAT ATT CCC TGC GCT GA & & \\
\hline Reverse & GCA GCT TTG AAT CCT GCT CT & & \\
\hline Ghrelin = GHRL & & 194 & 60 \\
\hline Forward & GCA TCC TCA AAG ACC AGG AG & & \\
\hline Reverse & CTT GAC ACT GGG GTT CCA CT & & \\
\hline GAPDH & & 294 & 58 \\
\hline Forward & AAG GGT GGA GCC AAA AGG & & \\
\hline Reverse & GGA TGC AGG GAT GAT GTT CT & & \\
\hline
\end{tabular}




\section{Results}

\subsection{Influence of Shikonin on Mice Propagative Organs}

The comparative analysis results of the female uterine organ coefficient, male seminal vesicle organ coefficient, sperm density and testicle organ coefficient among the control group and three experimental groups with shikonin concentrations of $5 \mathrm{mg} \cdot \mathrm{kg}^{-1}, 20 \mathrm{mg} \cdot \mathrm{kg}^{-1}$ and $50 \mathrm{mg} \cdot \mathrm{kg}^{-1}$ are shown in Figures 1-4. Figure 1 shows that the female uterine organ coefficient in the experimental group with the $50 \mathrm{mg} \cdot \mathrm{kg}^{-1}$ concentration was significantly lower than that of the control group and the other two experimental groups $(F=6.29, P<0.01)$. From the dissection results, there were no organic changes or lesions, including blackening, edema or congestion in the mice's uterine shape in the three experimental groups. However, the uterus of the experimental group with the $50 \mathrm{mg} \cdot \mathrm{kg}^{-1}$ concentration treatment appeared to clearly atrophy. As shown in Figure 2 and Figure 3, the seminal vesicle organ coefficient and sperm density of the male mice in the experimental group with the $50 \mathrm{mg} \cdot \mathrm{kg}^{-1}$ concentration were significantly lower than those of the control group $(F=6.49, P<0.01 ; F=4.60, P<0.05)$, which indicates that the seminal vesicle development and mature sperm number of the mice were suppressed. As shown in Figure 4, there were no significant differences for the testicle organ coefficient of the male mice among the experimental groups with different concentrations and the control group $(F=1.09, P>0.05)$. The

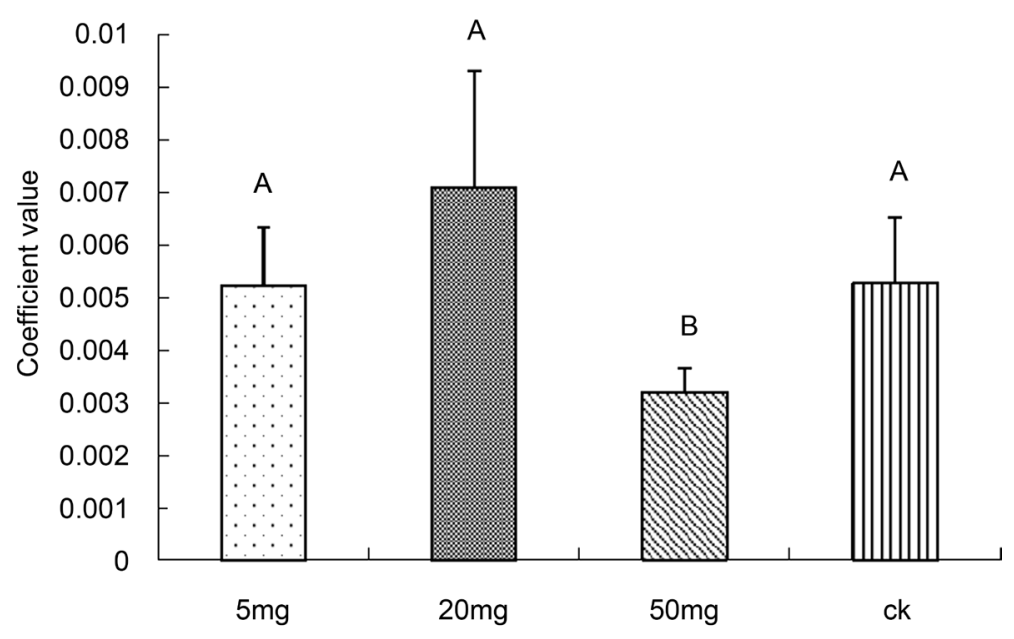

Figure 1. Comparison of female uterine organ coefficients between different experimental groups.

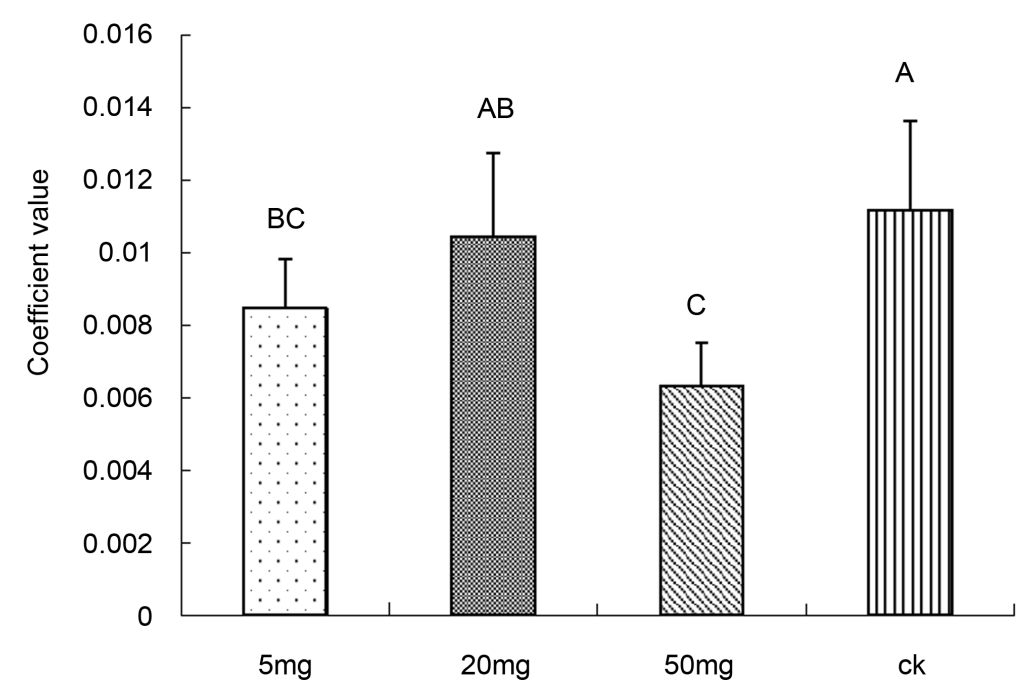

Figure 2. Comparison of male seminal vesicle coefficients between different experimental groups. 


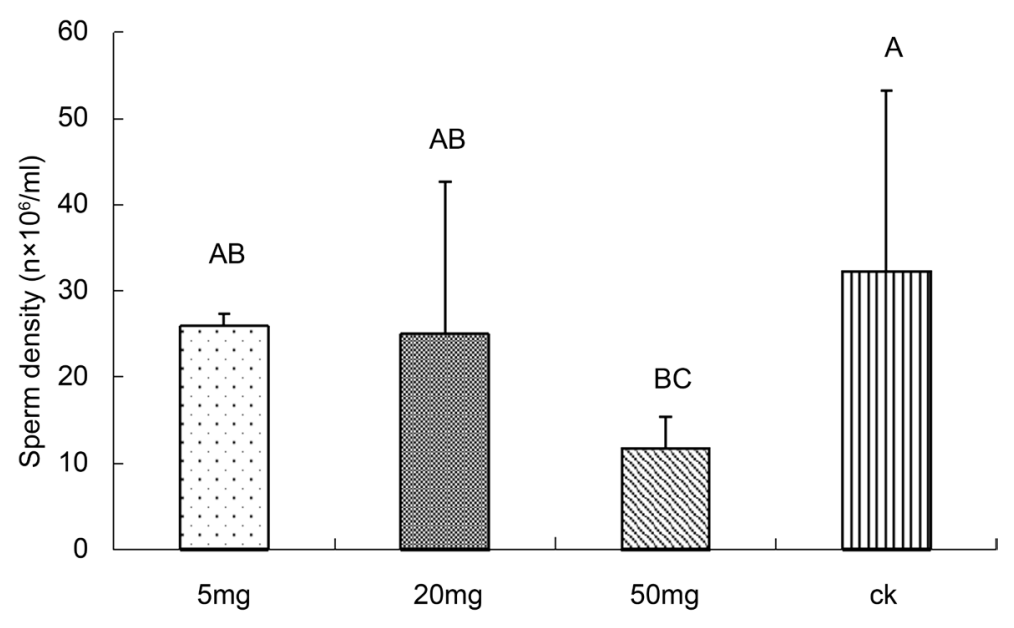

Figure 3. Comparison density of male sperm between different experimental groups.

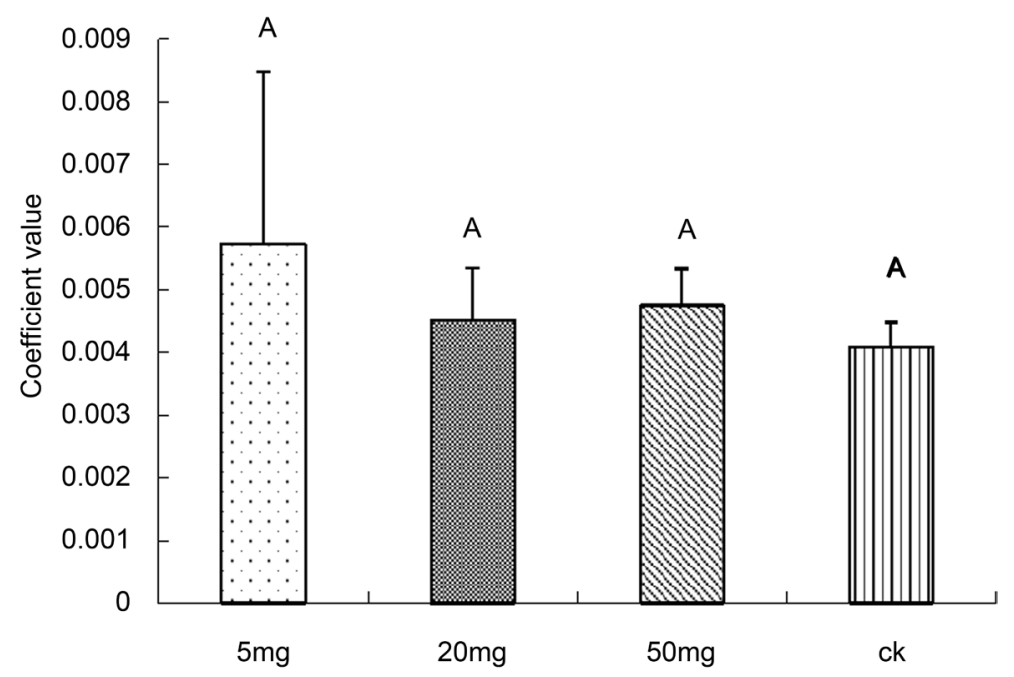

Figure 4. Comparison of male testicular coefficients between different experimental groups.

above results indicate that the experimental group with the $50 \mathrm{mg} \cdot \mathrm{kg}^{-1}$ concentration treatment had the expected anti-fertility effects.

\subsection{Influence of Shikonin on Mice Reproduction}

The $50 \mathrm{mg} \cdot \mathrm{kg}^{-1}$ concentration of shikonin was selected as the ideal concentration, and was compared with the control group for the reproduction tests. The number of offspring born to each pair in each group was recorded. The reproduction results of 13 pairs in each group were statistically analyzed, considering also accidental death during the experimental process, and the results are shown in Figure 5. There were no significant differences between the number of offspring in the first litter between the control group and male-treatment group. However, the female-treatment and female-male-treatment groups showed significant differences when compared with the other two groups $(F=14.78, P<0.001)$. Specifically, the number of offspring from the two experimental groups was significantly lower than that of the control group and the male-treatment group. However, there was no significant difference between the female-treatment and female-male-treatment groups, which indicates that the $50 \mathrm{mg} \cdot \mathrm{kg}^{-1}$ shikonin treatment could significantly decrease the birth rate of the female-treatment and female-male-treatment groups, but that it had no significant effects on the male-treatment group.

The number of offspring in the second litter are shown in Figure 6. There were differences in the number of 


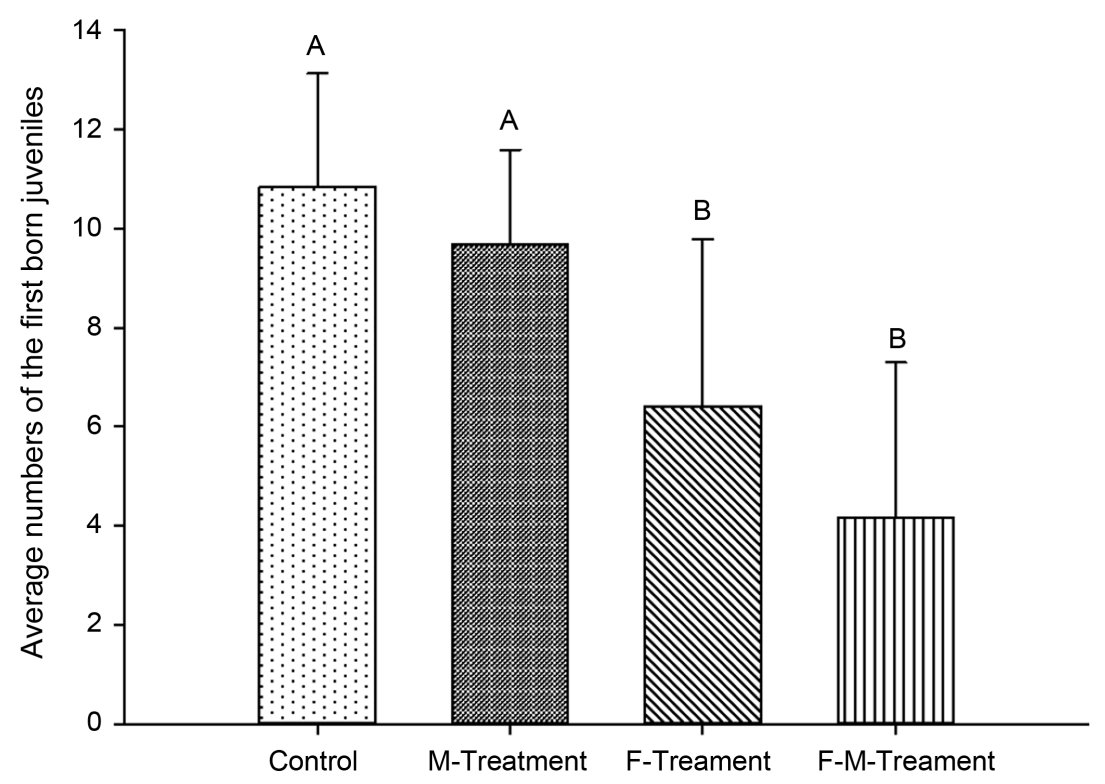

Figure 5. Comparison of first born juvenile numbers between different treatment groups. Note: The M-Treatment, F-Treatment and F-M-Treatment mean that males, females, and both females and males were treated by shikonin, respectively.

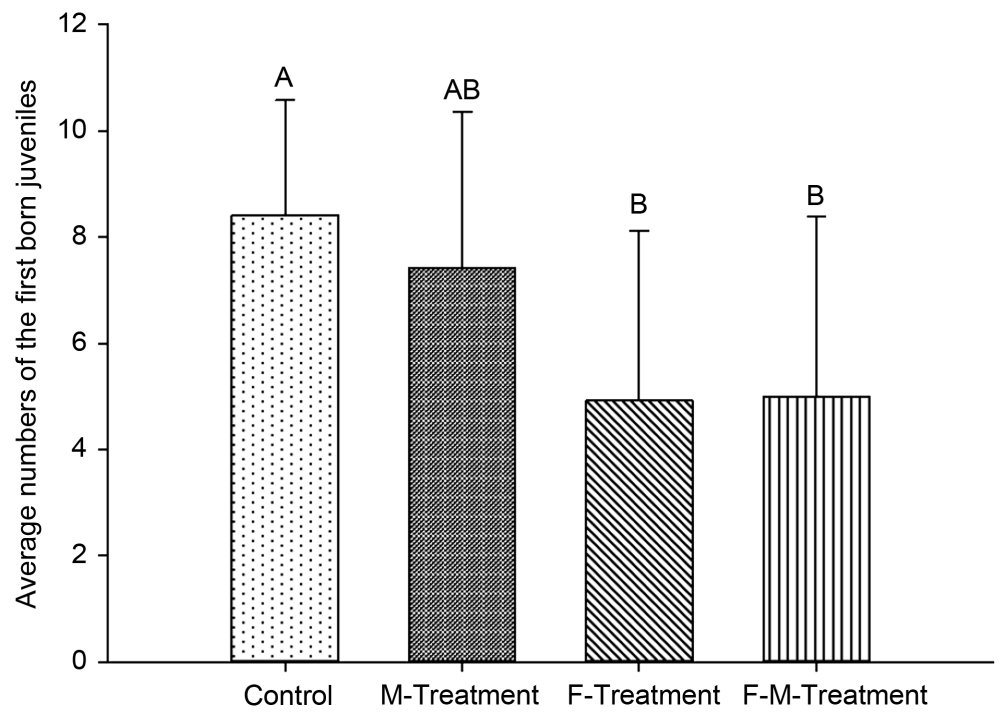

Figure 6. Comparison of second born juvenile numbers between different treatment groups. Note: The M-Treatment, F-Treatment and F-M-Treatment mean the same as Figure 5.

offspring from the first litter. The control group had no significant differences in the number of offspring compared to the male-treatment group, but there were significant differences when compared to the female-treatment and female-male-treatment groups $(F=4.23, P=0.0103)$. Specifically, the number of offspring from the latter two groups was significantly lower than that of the control group. However, the male-treatment group showed no significant differences when compared with the female-treatment or female-male-treatment groups. Therefore, $50 \mathrm{mg} \cdot \mathrm{kg}^{-1}$ shikonin had anti-fertility effects at the second reproduction event in the female-treatment and female-male-treatment groups, and non-significant effects on the male-treatment group, but it reduced the differences between the male-treatment group and the other two treatment groups.

\subsection{PCR Analysis}

Ghrelin was originally identified in 1999 as the endogenous ligand of the growth hormone (GH) secretagogue 
receptor (GHS-R) and it may operate at different levels of the reproductive system, including the testis and the ovary [20]. AgRP (agouti gene-related protein) neurons are closely related to Ghrelin [21]. Therefore, we analyzed its effects on mice reproduction. The results, as shown in Figure 7, showed that the level of AgRP and Ghrelin mRNA from the female ovary ( F-O = female-Ovary) of the treatment group mice $\left(50 \mathrm{mg} \cdot \mathrm{kg}^{-1}\right)$ are significantly higher than those of the control group ( $F=44.88, P<0.05 ; F=740.6, P<0.001)$. The level of AgRP and Ghrelin mRNA from male testis $\left(\mathrm{M}-\mathrm{T}=\right.$ Male-Testis) of the treatment group mice $\left(50 \mathrm{mg} \cdot \mathrm{kg}^{-1}\right)$ were also significantly higher than those of control group $(F=50.73, P<0.01$; $F=92.36, P<0.01)$. This showed that the AgRP and Ghrelin mRNA impacted on the reproduction of mice.

\section{Discussion}

The effective constituent of shikonin is a lipid soluble naphthoquinone compound, and it has traditionally been used to heal wounds, burns, dyspnea, hoarseness, hemorrhoids, abdominal aches, stomach ulcers and gynecological problems [15] [19]. Another similar shikonin extracted Onosma armeniacum has been analyzed for its contraceptive effects on embryo implantation in rats, but the fertility control mechanism was not analyzed, and the study only emphasized further clinical studies in Turkey [16]. This study based on wide distribution of Arnebia euchroma in China, and its extract shikonin was relatively easy obtainable due to the extraction process simple accurate [22]. The compositions of shikonin were pure natural compound, and that would almost not cause pollution to environment. Under the condition of natural sunlight more than 12 hours, or alkaline conditions ( $\mathrm{pH}>8$ ), shikonin would be biodegradable [23]. Therefore, we chose the extract shikonin of Arnebia euchroma as agent of infertility for wild small pest rodents fertility controlled, and firstly selected mice as experimental object to experiment research, obtained the expected effects.

The aim of all the experimental research into any sterilant is its practical application in the future. In the field, once the sterilant has been sprayed on grassland, both the male and female pest rodents would have a chance to consume it. Therefore, the ideal sterilant should have anti-fertility effects on the two genders simultaneously. Although the results from this study showed that there were no significant differences in the number of offspring
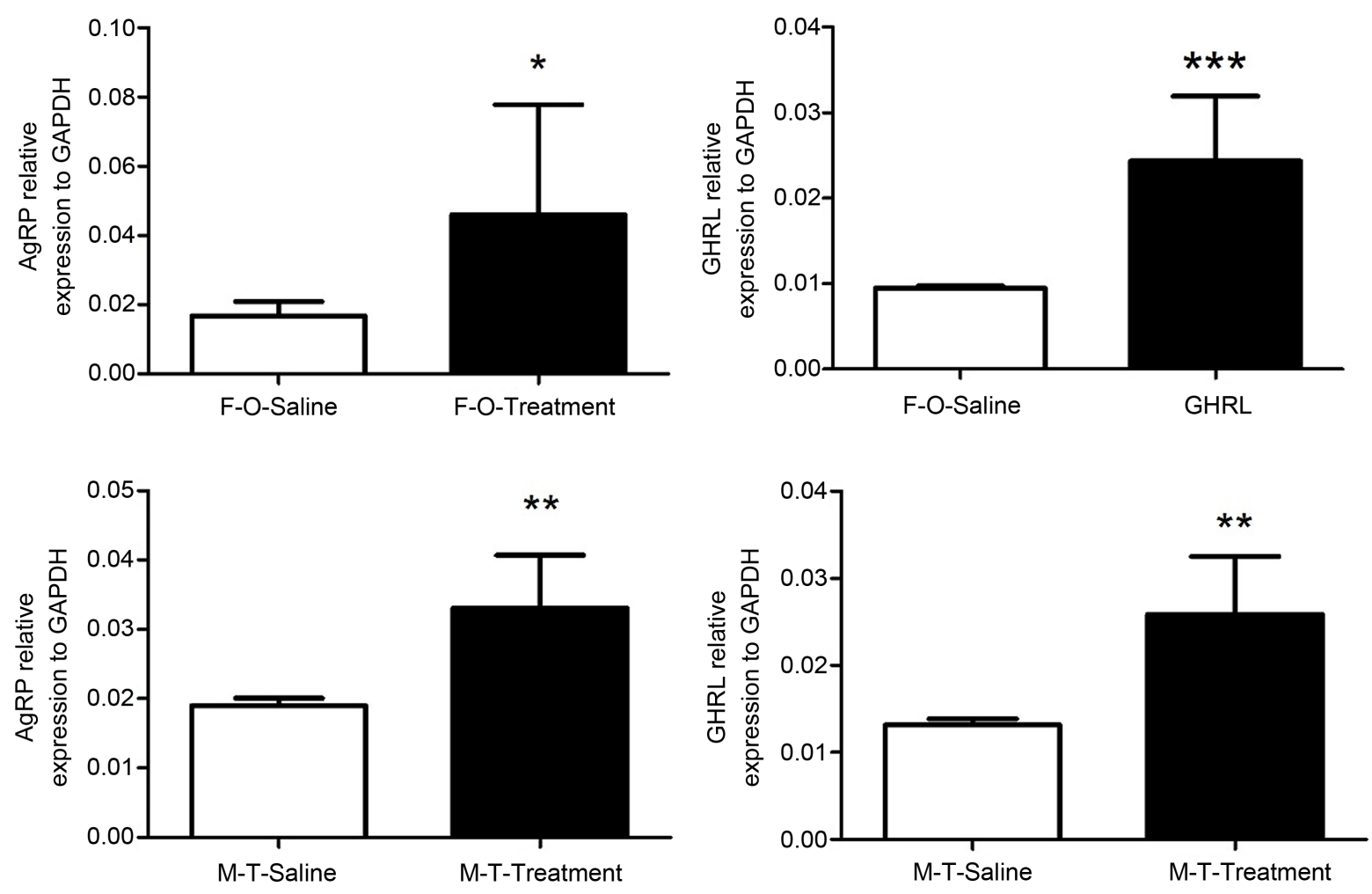

Figure 7. The PCR results of Ghrelin mRNA and AgRP neurons from mice ovaries and testicles. Note: F-O-Saline = femaleOvary Control Group; F-O-Treatment = Female-Ovary Treatment Group; M-T-Saline = Male-Testis Control Group; M-TTreatment $=$ Male-Testis Treatment Group. *means $P<0.05$; **means $P<0.01$; ***means $P<0.001$. 
born in the two reproduction events of the male-treatment group compared to the control group, the uteruses of the female mice in the $50 \mathrm{mg} \cdot \mathrm{kg}^{-1}$ experimental group appeared obviously atrophied, the development of the seminal vesicle in males was obviously suppressed, which indicated that shikonin produced certain effects on two sexual reproduction organs. Some researchers have suggested that some sterilants agents, such as EP-1, presented dose-dependent in applying [1] [4] [6]. But to the shikonin, to females, as Figure 1, the uterine organ coefficient of the experimental group with the $20 \mathrm{mg} \cdot \mathrm{kg}^{-1}$ was higher than other two experimental groups. According to dose-dependent, the value of the uterine organ coefficients of the group might be lower than that of the experimental group with the $5 \mathrm{mg} \cdot \mathrm{kg}^{-1}$, but the result was just opposite to dose-dependent. To males, as Figure 2, similar with Figure 1, the male seminal vesicle coefficients of the experimental group with the 20 $\mathrm{mg} \cdot \mathrm{kg}^{-1}$ was the similar result as the female uterine organ coefficients. Therefore, shikonin, as sterilant to mice, was not dose-dependent. Research has shown that the shikonin could inhibit the effects of estrogen, and the molecular mechanism has found that protein expression of estrogen receptor $\mathrm{ER} \alpha$ (estrogen receptor- $\alpha$ ) was suppressed. Shikonin can promote the degradation of ER $\alpha$, lead to HSP90 (heat shock proteins 90) molecular chaperone protein decomposition by the pathway of ubiquitin-protease, and induce Nrf2 (nuclear factor-erythroid 2 p45-related factor 2) dependence of NQO1 $(\mathrm{NAD}(\mathrm{P}) \mathrm{H}$ : quinone oxidoreductase) gene transcription and abate estrogen gene expression, to inhibit the activation of ER $\alpha$ signals and NQO1, thus inhibiting activity of estrogen [24] [25]. This was consistent with the result that the female mice uterine appeared obvious atrophy of the experimental groups in this study. Research on the mechanism of male mice reproductive suggests that estrogen mediated by ER $\alpha$ plays an important role in spermatogenesis, and ER $\alpha$ gene of mice was damaged (suppressed) accompanying spermatogenic epithelium damaged, sperm counts reducing, sperm morphology abnormal and reproductive ability declining [26] [27] which was accordant with the result that the male mice sperm density decreased significantly of $50 \mathrm{mg} \cdot \mathrm{kg}^{-1}$ shikonin concentration group. Shikonin, therefore, as plant source sterile agent, would have more ideal effects for functioned both sexes sterility.

Although the results from this study showed that the development of the seminal vesicle in males was obviously suppressed, and the male mice sperm density decreased significantly, there were no significant differences in the number of offspring born in the two reproduction events of the male-treatment group compared to the control group. We inferred the reasons as follows: To the male-treatment group, the fertilization rates of the first and second reproduction were $86.67 \%$ and $73.33 \%$, respectively. These of the control group were $86.67 \%$ and $80.00 \%$, respectively. The differences of the twice fertilization rates between the male-treatment and control groups were little. On the other hand, litter sizes of the first and second reproduction were $9.7 \pm 1.8$ and $8.2 \pm$ 1.2 of the male-treatment group, respectively. These of the control group were $10.9 \pm 2.2$ and $8.4 \pm 1.4$, respectively. The differences of the twice litter size between the male-treatment and control groups were not significant $(F=0.74, P>0.05 ; F=1.71, P>0.05)$ which means the sperm motility not reduced and the sperm density declined not enough to influence the number of juveniles significantly. The results maybe are relevant with duration of experiments. In this study, the sperm counts of male-treatment group reduced by $63.72 \% \pm 8.55 \%$, if they were infertility, both of sperm counts and motility would be reduction [28]. But, how to regulate mice sperm motility is our experiments in future.

Ghrelin, an endogenous ligand of the growth hormone secretagogue receptor (GHS-R), has been isolated and purified from mice gastric mucosa. Ghrelin is a multifunctional brain-gut peptide and it plays an important role in the regulation of mammal metabolism [29]. AgRP neurons play an important role in controlling meal patterns, linking changes in food availability to the activity of these neurons as part of a learned behavioral change that allows animals to adapt to changing environmental conditions [21]. However, how did the AgRP and Ghrelin mRNA impact on the reproduction of mice?

The ghrelin neurons in the hypothalamus are adjacent to the active sites of the AgRP neuronal synapse. Peripheral ghrelin is untied with or through GHS-R to increase the activity of the AgRP neurons (ghrelin activates NPY/AgRP neurons), and the AgRP secretes a neuropeptide to promote animal ingestion [30]. Ghrelin interacts with AgRP neuron cells to regulate animal metabolism. Research in recent years has indicated that ghrelin has a close relationship with the regulation of reproduction in mammals. The relationship between ghrelin and energy balance as well as reproduction was discussed [31]. It was found that ghrelin might be involved in the regulation of gonadotropin secretion and it affects the mammalian estrus. The effects on reproduction and regulation caused by ghrelin were studied by Garcia et al. (2007) and Tena-Sempere et al. (2007) respectively, who found that ghrelin had effects on the reproduction of rodents through directly acting on the sex gland or regulating the sex gland secretions [32] [33]. Lorenzi et al. (2009) and Muccioli et al. (2011) studied the effects of ghrelin on 
mammalian reproduction through metabolism, and they found that ghrelin had effects on animal reproduction through the regulation of the pituitary gonadal axis [34] [35]. Based on the above analyses, and combined with the results achieved in this study, it is suggested that the anti-fertility effect of shikonin in mice could be used to control reproduction in mice via the regulation of the pituitary gonadal axis.

\section{Acknowledgements}

We would thank Prof. Andreas Wilkes and Prof. Guo-dong Han for revising our manuscript, thank Prof. Yunsheng Zheng, Zhen-ying Li and Cheng-guang Du who are from Vocational and Technological College of Inner Mongolia Agricultural University, who helped in the experiments. This study was supported by grants from the Natural Science Foundation of China (Grant No. 31260580, 31560669, 30760044), the Grassland Resource Innovative Research Team supported by the Ministry of Education of China (Grant No. IRT 1259), the Natural Science Foundation of Inner Mongolia (Grant No. 2014 MS0325) and the Commonweal Profession Project of the Ministry of Agriculture of China (Grant No. 201203041).

\section{References}

[1] Wan, X.R., Shi, Y.S., Bao, X., et al. (2006) Effect of the Contraceptive Compound (EP-1) on Reproduction of the Djungarian Hamster (Phodopus campbelli) in the Typical Steppe. Acta Theriologica Sinica, 26, 392-397. http://www.mammal.cn//CN/article/downloadArticleFile.do?attachType=PDF\&id=2089

[2] Acob, J. and Rahmini, S. (2006) The Impact of Imposed Female Sterility on Field Populations of Rice-Field Rats (Rattus argentiventer). Agriculture Ecosystems \&Environment, 115, 281-284. http://www.sciencedirect.com/science/article/pii/S0167880906000065 http://dx.doi.org/10.1016/j.agee.2006.01.001

[3] Jacob, J., Singleton, G.R. and Hinds, L.A. (2008) Fertility Control of Rodent Pests. Wildlife Research, 35, 487-493. http://www.publish.csiro.au/paper/WR07129.htm http://dx.doi.org/10.1071/WR07129

[4] Zhao, M., Liu, M., Li, D., et al. (2007) Anti-Fertility Effect of Levonorgestrel and Quinestrol in Brandt's Voles (Lasiopodomys brandtii). Integrative Zoology, 2, 260-268. http://dx.doi.org/10.1111/j.1749-4877.2007.00059.X

[5] Liu, M., Qu, J.P., Yang, M., et al. (2012) Effects of Quinestrol and Levonorgestrel on Populations of Plateau Pikas, Ochotona curzoniae, in the Qinghai-Tibetan Plateau. Pest Management Science, 68, 592-601. http://dx.doi.org/10.1002/ps.2302

[6] Fu, H.P., Zhang, J.W., Shi, D.Z. and Wu, X.D. (2013) Effects of Contraception Control on Mongolian Gerbil Wild Populations: A Case Study. Integrative Zoology, 8, 277-284. http://dx.doi.org/10.1111/1749-4877.12018

[7] Zhang, Z.B. (1995) The Ecological Fundamentals of Rodent Control by Contraception. Acta Theriologica Sinica, 15, 229-234. http://www.mammal.cn//CN/article/downloadArticleFile.do?attachType=PDF\&id=1641

[8] Zhang, Z.B. (2000) Mathematical Models of Wildlife Management by Contraception. Ecological Modelling, 132, 105113. http://www.sciencedirect.com/science/article/pii/S0304380000003082 http://dx.doi.org/10.1016/s0304-3800(00)00308-2

[9] Barlow, N.D., Kean, J.M. and Briggs, C.J. (1997) Modelling the Relative Efficacy of Culling and Sterilisation for Controlling Populations. Wildlife Research, 24, 129-141. http://www.publish.csiro.au/paper/WR95027.htm http://dx.doi.org/10.1071/WR95027

[10] Shi, D., Wan, X., Davis, S., Pech, R. and Zhang, Z. (2002) Simulation of Lethal and Fertility Control in a Demographic Model for Brandt's Vole Microtus brandti. Journal of Applied Ecology, 39, 337-348. http://dx.doi.org/10.1046/j.1365-2664.2002.00716.x

[11] Liu, H.W., Zhou, L., Liu, W. and Zhou, H.K. (2008) Theoretical Model of Ochotona curzoniae Control via Contraception. Chinese Journal of Ecology, 27, 1238-1243. http://www.cje.net.cn/CN/article/downloadArticleFile.do?attachType=PDF\&id=252

[12] Liu, H.W., Jin, Z., Zhang, F.Q. and Li, Q.Y. (2013) Dynamic Model of Seasonal Breeding Rodent Pest Population Controlled with Short-Acting Sterilant. Chinese Journal of Applied Ecology, 24, 1141-1145. http://www.cjae.net/CN/article/downloadArticleFile.do?attachType=PDF\&id=19031

[13] Tran, T.T. and Hinds, L.A. (2013) Fertility Control of Rodent Pests: A Review of the Inhibitory Effects of Plant Extracts on Ovarian Function. Pest Management Science, 69, 342-354. http://dx.doi.org/10.1002/ps.3354

[14] Liu, H.W., Wang, R.X., Zhang, F.Q. and Li, Q.Y. (2011) Research Advances of Contraception Control of Rodent Pest in China. Acta Ecologica Sinica, 31, 5484-5494. 
[15] Chen, X., Yang, L., Oppenheim, J.J. and Howard, O.M. (2002) Cellular Pharmacology Studies of Shikonin Derivatives. Phytotherapy Research, 16, 199-209. http://dx.doi.org/10.1002/ptr.1100

[16] Salman, S., Kumbasar, S., Ozgen, U., Erdogan, F. and Suleyman, H. (2009) Contraceptive Effects of Onosma armeniacum on Embryo Implantation in Rats. Cell Membranes and Free Radical Research, 1, 90-94.

[17] Lee, H., Kang, R. and Yoon, Y. (2010) Shikonin Inhibits Fat Accumulation in 3T3-L1 Adipocytes. Phytotherapy Research, 24, 344-351. http://onlinelibrary.wiley.com/doi/10.1002/ptr.2942/full http://dx.doi.org/10.1002/ptr.2942

[18] Chinese Pharmacopoeia Commission (CPC) (2010) Pharmacopoeia of the People's Republic of China. Chinese Medical Science and Technology Press, Beijing.

[19] Yin, J. and Guo, L.G. (1994) Modern Research and Clinical Application on Chinese Traditional Medicine. Academy Press, Beijing.

[20] Barreiro, M.L. and Tena-Sempere, M. (2004) Ghrelin and Reproduction: A Novel Signal Linking Energy Status and Fertility? Molecular and Cellular Endocrinology, 226, 1-9. http://dx.doi.org/10.1016/j.mce.2004.07.015

[21] Tan, K., Knight, Z.A. and Friedman, J.M. (2014) Ablation of AgRP Neurons Impairs Adaption to Restricted Feeding. Molecular Metabolism, 3, 694-704. http://dx.doi.org/10.1016/j.molmet.2014.07.002

[22] Wu, X.Y. and Liu, P. (2008) Optimization on Alcohol Extraction Technology of Radix Arnebiae by Orthogonal Design. Evaluation and Analysis of Drug-Use in Hospitals of China, 8, 750-752.

[23] Qiao, X.W., Dan, J.M., Zeng, X.J., Du, Z. and Liu, C. (2004) The Physicochemical Properties of Nuphtheroquinon Pigment of Amebia Euehroma from Xinjiang. Guangzhou Food Science and Technology, 20, 70-72.

[24] Yao, Y., Brodie, A.M., Davidson, N.E., Kensler, T.W. and Zhou, Q. (2010) Inhibition of Estrogen Signaling Activates the NRF2 Pathway in Breast Cancer. Breast Cancer Research and Treatment, 124, 585-591. http://dx.doi.org/10.1007/s10549-010-1023-8

[25] Xu, J. and Wu, C.L. (2015) Theresearch Progress of Shikonin Pharmacological Effect. Pharmaceutical Biotechnology, 22, 87-90.

[26] Hess, R.A., Zhou, Q., Nie, R., et al. (2001) Estrogens and Epididymal Function. Reproduction Fertility and Development, 13, 273-283. http://dx.doi.org/10.1071/RD00100

[27] Zhou, Q., Clarke, L., Nie, R., et al. (2001) Estrogen Action and Male Fertility: Roles of the Sodium/Hydrogen Exchanger-3 and Fluid Reabsorption in Reproductive Tract Function. Proceedings of the National Academy of Sciences of the United States of America, 98, 14132-14137. http://dx.doi.org/10.1073/pnas.241245898

[28] Hermo, L., Chung, S., Gregory, M., et al. (2008) Alterations in the Testis of Hormone Sensitive Lipase-Deficient Mice Is Associated with Decreased Sperm Counts, Sperm Motility, and Fertility. Molecular Reproduction and Development, 75, 565-577. http://dx.doi.org/10.1002/mrd.20800

[29] Kojima, M., Hosoda, H., Date, Y., Nakazato, M., Matsuo, H. and Kangawa, K. (1999) Ghrelin Is a Growth-HormoneReleasing Acrylate Peptide from Stomach. Nature, 402, 656-660. http://dx.doi.org/10.1038/45230

[30] Stark, R., Ashley, S.E. and Andrews, Z.B. (2013) AMPK and the Neuroendocrine Regulation of Appetite and Energy Expenditure. Molecular and Cellular Endocrinology, 366, 215-223. http://dx.doi.org/10.1016/j.mce.2012.06.012

[31] Fernandez-Fernandez, R., Martini, A.C., Navarro, V.M., et al. (2006) Novel Signals for the Integration of Energy Balance and Reproduction. Molecular and Cellular Endocrinology, 25, 254-255.

[32] García, M.C., López, M., Alvarez, C.V., et al. (2007) Role of Ghrelin in Reproduction. Reproduction, 133, 531-540. http://dx.doi.org/10.1530/REP-06-0249

[33] Tena-Sempere, M. (2007) Roles of Ghrelin and Leptin in the Control of Reproductive Function. Neuroendocrinology, 86, 229-241. http://dx.doi.org/10.1159/000108410

[34] Lorenzi, T., Meli, R., Marzioni, D., et al. (2009) Ghrelin: A Metabolic Signal Affecting the Reproductive System. Cytokine \& Growth Factor Reviews, 20, 137-152. http://dx.doi.org/10.1016/j.cytogfr.2009.02.003

[35] Muccioli, G., Lorenzi, T., Lorenzi, M., et al. (2011) Beyond the Metabolic Role of Ghrelin: A New Player in the Regulation of Reproductive Function. Peptides, 32, 2514-2521. http://dx.doi.org/10.1016/j.peptides.2011.10.020 


\section{Submit or recommend next manuscript to SCIRP and we will provide best service for you:}

Accepting pre-submission inquiries through Email, Facebook, LinkedIn, Twitter, etc.

A wide selection of journals (inclusive of 9 subjects, more than 200 journals)

Providing 24-hour high-quality service

User-friendly online submission system

Fair and swift peer-review system

Efficient typesetting and proofreading procedure

Display of the result of downloads and visits, as well as the number of cited articles

Maximum dissemination of your research work

Submit your manuscript at: http://papersubmission.scirp.org/ 